\title{
Application of the Haug model for process design of petroleum hydrocarbon-contaminated soil bioremediation by composting process
}

\author{
M. Khamforoush • M.-J. Bijan-Manesh • \\ T. Hatami
}

Received: 15 February 2012/Revised: 3 June 2012/Accepted: 10 October 2012/Published online: 7 November 2012

(C) CEERS, IAU 2012

\begin{abstract}
The main scope of this work is applying an aerobic composting model for remediation of petroleum hydrocarbon-contaminated soil. For this purpose, the reaction kinetics was integrated with the mass and energy balances over the composting system. Literature pilot scale data for bioremediation of diesel oil-contaminated soil was used for model validation. Comparisons of simulation results with experimental data for diesel concentration and oxygen concentration showed good agreement during the remediation process. With validated model for bioremediation of diesel oil-contaminated soil, the influence of amendment type, bulking agent, amendment/soil ratio, bulking agent/soil ratio, moisture content and airflow rate were investigated on diesel biodegradation. The simulation results showed that maximum degradation of diesel occurred in the presence of yard waste as amendment. Furthermore, addition of bulking agent (wood chips) increased the diesel degradation about $6 \%$. In presence of yard waste as amendment and wood chips as bulking agent, the optimal values for maximum remediation were amendment/soil ratio $\left(2.5 \mathrm{~kg} \mathrm{~kg}^{-1}\right)$, bulking agent/soil ratio $\left(2.25 \mathrm{~kg} \mathrm{~kg}^{-1}\right)$, initial moisture content $(62.5 \%)$ and airflow $\left(0.520 \mathrm{~m}^{3}\right.$ day $\left.^{-1} \mathrm{kgBVS}^{-1}\right)$.
\end{abstract}

Keywords Aerobic composting - Mathematical modeling · Optimization · Soil remediation simulation

M. Khamforoush ( $₫) \cdot$ M.-J. Bijan-Manesh · T. Hatami Department of Chemical Engineering, Faculty of Engineering, University of Kurdistan, 66177 Sanandaj, Iran

e-mail: m.khamforoush@uok.ac.ir

\section{Introduction}

Every year, large amounts of petroleum and petroleum hydrocarbons enter the environment because of human activities and unforeseeable accidents (Zhu et al. 2001). These penetrated oils remain unchanged for a long time inside the soil and have a great potential to cause serious damage to natural ecosystems (Obire and Anyanwu 2009). Therefore, soil pollution by petroleum products is a common problem in the world, which causes lots of concern (Megharaj et al. 2011; Riser-Roberts 1992). It has been well established that bioremediation technologies are suitable techniques to clean up chemically polluted soils (Abdulsalam et al. 2011; Megharaj et al. 2011). Up to date, several bioremediation techniques have been reported to clean up soils contaminated with hazardous chemicals (Abdulsalam et al. 2011; Adams and Guzmán-Osorio 2008; Bento et al. 2005; Chaineau et al. 2005; Fountoulakis et al. 2009; Gallego et al. 2001; Jorgensen et al. 2000; Megharaj et al. 2011; Yousefi Kebria et al. 2009; Zhao et al. 2010). Due to low capital and operating costs, simplicity of operation and design, and relatively high treatment, composting technique is preferred in comparison with the other methods (Namkoong et al. 2002; Van Gestel et al. 2003).

Generally, the composting process is applied to decompose and stabilize organic solid wastes including; yard wastes, agricultural crops, food wastes, manure, municipal solid wastes, sewage and industrial sludge (Haug 1993). Furthermore, it has been demonstrated that composting could be employed as an effective method for remediation of oil-contaminated soils (Antizar-Ladislao et al. 2004; Al-Daher et al. 1998; Bento et al. 2005; Freeman and Harris 1995; Hwang et al. 2006; Megharaj et al. 2011; Namkoong et al. 2002; Van Gestel et al. 2003). Up to now, various experimental studies have been 
accomplished for remediation of oil-contaminated soils by composting. However, due to the large number of affecting parameters in composting process and time consuming nature of the process, determination of optimum condition for maximum removal of hydrocarbons from polluted soil is experimentally impossible. Therefore, employing modeling techniques to determine the optimum condition for remediation process is inevitable. To the best of the authors' knowledge, modeling of contaminated soil remediation by composting process has not yet been reported in literature.

The main objective of this study was to apply a mathematical model for remediation of petroleum hydrocarboncontaminated soil by aerobic composting process and validate this model with experimental data. To validate the model, a typical published experimental data of diesel oil-contaminated soil bioremediation using composting process (Van Gestel et al. 2003) was utilized. Furthermore, the effects of various parameters on diesel decomposition were investigated using the developed simulator, and optimum condition for maximal removal of diesel from polluted soil was determined. It is not necessary to say that the developed simulator can also be employed to simulate remediation of soil polluted by any other types of petroleum hydrocarbon.

\section{Materials and methods}

\section{Modeling and simulation method}

The mathematical modeling and simulation in this work is a direct application of the Haug's model (1993) to the literature experimental data of petroleum hydrocarbon-contaminated soil remediation. The model is based on chemical reaction engineering principles as well as mass and energy balances equations. A three-phase system including solid phase or dry substrate, liquid phase or water and gas phase has been considered for model description. The dry substrate consisted of organic and inorganic part. The organic solid part has been divided also into biodegradable volatile solid (BVS) and non-biodegradable volatile solid (NBVS) components. BVS component of dry substrate is degraded due to bacterial activities during the aerobic composting process. So, oxygen is consumed and carbon dioxide, water and ammonia are produced. Furthermore, heat is released due to organic oxidation (exothermic reaction) of BVS component.

The liquid phase of the system is water. Water either enters the system along with wet substrate, or is produced in the system by organic decomposition of the BVS component. Moreover, as composting is a dehydrating process, supplemental water must be added to the system.
The gas phase comprised of several components including: nitrogen, oxygen, water vapor, carbon dioxide, and ammonia. The first three components enter the system by input air. Water vapor and the last two components are produced by organic oxidation of BVS.

Once system components were determined, the degradation kinetics was coupled with mass and energy balances equations and the composting state variables were determined. State variables were defined as the variables that describe the system components' properties at different conditions. The most important state variables are temperature, moisture content, and oxygen mass fraction. To simplify the modeling approach, the following assumptions were considered:

- The entire composting process is broken into a number of well-mixed series reactors/stages.

- Model parameters are lumped over each stage.

- The gas phase is ideal.

- Composting operation is accomplished at constant pressure.

- Heat capacities of system components are constant.

- Enthalpies are pressure independent.

- pH effects are negligible.

- Petroleum hydrocarbons considered as a part of the solid phase.

\section{Process kinetics and stoichiometry}

The composting kinetics is a complex subject and reaction rates can be limited by several factors including moisture content, free air space, oxygen concentration, lack of degradable organics, process temperature, imbalanced $\mathrm{pH}$ conditions, lack of inorganic nutrients, lack of microbes, and the toxic substance (Haug 1993; Mason 2006). Therefore, a complete mathematical description of composting kinetics based on first principles is not possible. To overcome this problem in the modeling of composting process, usually the first order kinetics is considered for BVS degradation and the effects of other parameters on reaction kinetics are imposed by empirical relations (Haug 1993). According to Mason review for composting modeling (Mason 2006), first-order kinetics model with empirical corrections for temperature, moisture, oxygen concentration and free air space are generally successful in predicting the evolution of dynamic state variables (temperature, solids, moisture, oxygen and carbon dioxide concentration). Furthermore, using the first-order kinetics model for degradation of organic materials and petroleum hydrocarbons has been previously justified by several authors (Jorgensen et al. 2000; Hwang et al. 2006; Namkoong et al. 2002; Van Gestel et al. 2003), among others. So, the first-order kinetics model (Haug 1993; 
Mason 2006; Petric and Selimbasic 2008) with empirical corrections for temperature, moisture, oxygen concentration and free air space was considered as follows for biodegradation process and the effects of the other factors were ignored:

$\frac{d(B V S)}{d t}=-k B V S$.

Here, $B V S$ is the mass of biodegradable volatile solid matter in the substrate $(\mathrm{kg}), t$ is time of the remediation process (day), and $k$ is the decomposition reaction rate constant $\left(\right.$ day $\left.^{-1}\right)$. BVS was degraded according to the following reaction (Haug 1993; Petric and Selimbasic 2008):

$$
\begin{aligned}
& \mathrm{C}_{a} \mathrm{H}_{b} \mathrm{O}_{c} \mathrm{~N}_{d}+\frac{(4 a+b-3 d-2 c)}{4} \mathrm{O}_{2} \longrightarrow a \mathrm{CO}_{2} \\
& +\frac{b-3 d}{2} \mathrm{H}_{2} \mathrm{O}+d \mathrm{NH}_{3} .
\end{aligned}
$$

The general formulas of substrates were adapted from Haug (1993). Due to the complex behavior of the composting process, $B V S$ degradation was assumed to be influenced only by temperature, moisture content, oxygen concentration and free air space (FAS). According to Haug's handbook (1993) the reaction rate constant can be corrected as follows:

$k=k_{T} F 1 F 2 F \mathrm{O}_{2}$

where $k_{T}$ is temperature correction function, and $F 1, F 2$ and $\mathrm{FO}_{2}$ correct the effect of moisture content, free air space (FAS) and oxygen concentration on the biodegradation rate constant, respectively. In this study, the proposed temperature correction factor of Haug (1993) was adopted using the following equation:

$k_{T}=k_{T 20}\left[1.066^{(T-20)}-1.21^{(T-60)}\right]$

where $k_{T 20}$ is the maximum reaction rate constant at temperature $20^{\circ} \mathrm{C}\left(\right.$ day $\left.^{-1}\right)$, and $T$ is the substrate temperature $\left({ }^{\circ} \mathrm{C}\right)$. Haug (1993) also proposed the following correction functions for $F 1, F 2$ and $\mathrm{FO}_{2}$ :

$$
\begin{aligned}
& F 1=\frac{1}{e^{\left[-17.684\left(1-S_{\mathrm{m}}\right)+7.0622\right]}+1} \\
& F 2=\frac{1}{e^{[-23.675 \mathrm{FAS}+3.4945]}+1} \\
& F \mathrm{O}_{2}=\frac{\mathrm{VPO}_{2}}{\mathrm{VPO}_{2}+2}
\end{aligned}
$$

In the above equations, $S_{\mathrm{m}}$ is solid content fraction of the substrate. $\mathrm{VPO}_{2}$ is the volume percent of oxygen in the exhaust gases from the composting process. Free air space (FAS) was calculated according to the following relations (Haug 1993):
$\mathrm{FAS}=1-\frac{\delta_{\mathrm{m}} S_{\mathrm{m}}}{G_{\mathrm{m}} \delta_{\mathrm{w}}}-\frac{\delta_{\mathrm{m}}\left(1-S_{\mathrm{m}}\right)}{\delta_{\mathrm{w}}}$

$\frac{1}{G_{\mathrm{m}}}=\frac{V_{\mathrm{s}}}{G_{\mathrm{v}}}+\frac{1-V_{\mathrm{s}}}{G_{\mathrm{f}}}$

$\delta_{\mathrm{m}}=\frac{C}{S_{\mathrm{m}}}$

Here, $\delta_{\mathrm{m}}$ and $\delta_{\mathrm{w}}$ stand for the substrate mixture density and water density $\left(\mathrm{kg} \mathrm{m}^{-3}\right)$, respectively. $G_{\mathrm{m}}, G_{\mathrm{v}}$ and $G_{\mathrm{f}}$ stand for the solids' mixture specific gravity, solids' volatile fraction specific gravity $(=1)$ and solids' fixed fraction (ash) specific gravity $(=2.5)$, respectively. $V_{\mathrm{s}}$ stand for the solids volatile fraction and $C$ stands for the substrate mixture bulk weight coefficient (0.15-0.4).

\section{Mass balance}

Mass balance analysis must be applied over all components which enter to and exit from the three-phase system boundaries. The necessary independent mass balance equations were applied for solid, gas and liquid phase in the following three subsections so that the modeling of composting has a unique solution.

Solid phase mass balance Applying conservation of mass, the following equation can be written for the solid phase:

$m_{\mathrm{so}}=m_{\mathrm{si}}-m_{\mathrm{DBVS}}$

where $m_{\mathrm{so}}, m_{\mathrm{si}}$, and $m_{\mathrm{DBV} s}$ are the mass flow rate $\left(\mathrm{kg} \mathrm{day}^{-1}\right)$ of output solid substrates, input solid substrates, and decomposed volatile solids, respectively.

Gas phase mass balance The gas phase consists of dry air, water vapor, carbon dioxide, and ammonia. The mass flow rate of input dry air and water vapor to the system were calculated based on the following equations (Haug 1993):

$m_{\text {airi }}=\frac{28.96(P-\mathrm{PV}) Q_{\mathrm{air}}}{R\left(T_{\mathrm{air}}+273\right)}$

$m_{\mathrm{wvi}}=\frac{18.015 \mathrm{PV} Q_{\text {air }}}{R\left(T_{\text {air }}+273\right)}$

$\mathrm{PV}=\mathrm{RH} * \mathrm{PVS}$

where $m_{\text {airi }}$ is the mass flow rate of the input dry air $\left(\mathrm{kg} \mathrm{day}^{-1}\right), m_{\mathrm{wvi}}$ is the mass flow rate of the input water vapor $\left(\mathrm{kg} \mathrm{day}^{-1}\right), P$ is the atmosphere absolute pressure $(\mathrm{mmHg}), \mathrm{PV}$ is the actual water vapor pressure in the input air $(\mathrm{mmHg}), Q_{\text {air }}$ is the input air flow rate $\left(\mathrm{m}^{3} \mathrm{day}^{-1}\right), R$ is the universal gas constant $\left(0.062364 \mathrm{mmHg} \mathrm{m} \mathrm{k}^{-1} \mathrm{~mol}^{-1}\right)$, $T_{\text {air }}$ is the ambient air temperature $\left({ }^{\circ} \mathrm{C}\right), \mathrm{RH}$ is the relative 
humidity of input air, and PVS is the saturation water vapor pressure in the input air $(\mathrm{mmHg})$.

The mass flow rate of output dry gases and water vapor were calculated using the following equations (Haug 1993):

$m_{\text {gaso }}=m_{\text {airi }}+m_{\mathrm{CO}_{2}}+m_{\mathrm{NH}_{3}}-m_{\mathrm{O}_{2}}$

$m_{\mathrm{wvo}}=m_{\mathrm{gaso}} \frac{18.015}{28.96} \frac{\mathrm{PVO}}{P-\mathrm{PVO}}$

$\mathrm{PVO}=\mathrm{PV}+(\mathrm{PVSO}-\mathrm{PV}) F 1$

where $m_{\text {gaso }}$ is the mass flow rate of output dry gas $\left(\mathrm{kg}\right.$ day $\left.{ }^{-1}\right), m_{\mathrm{CO}_{2}}$ is the mass flow rate of generated $\mathrm{CO}_{2}$ $\left(\mathrm{kg} \mathrm{day}^{-1}\right), m_{\mathrm{NH}_{3}}$ is the mass flow rate of generated $\mathrm{NH}_{3}$ $\left(\mathrm{kg} \mathrm{day}^{-1}\right), m_{\mathrm{O}_{2}}$ is the mass flow rate of consumed oxygen in organic decomposition reaction $\left(\mathrm{kg} \mathrm{day}^{-1}\right), m_{\mathrm{wvo}}$ is the mass flow rate of output water vapor $\left(\mathrm{kg} \mathrm{day}^{-1}\right)$, PVO is the actual water vapor pressure in the exit gas $(\mathrm{mmHg})$, and PVSO is the saturation water vapor pressure in the exhaust gas. The calculation details of generated/consumed components were given by Haug (1993).

Liquid phase mass balance As mentioned previously, liquid phase is totally composed of water. Water enters the process from various sources including; substrates water content, generated water due to decomposition reaction and supplemental water, which maintains appropriate moisture content in the process.

The following equation was developed for the water balance in the composting process:

$m_{\mathrm{wso}}=m_{\mathrm{wsi}}+m_{\mathrm{wp}}+m_{\mathrm{wad}}+m_{\mathrm{wvi}}-m_{\mathrm{wvo}}$

where $m_{w s o}$ is the mass flow rate of water in output solids, $m_{\mathrm{wsi}}, m_{\mathrm{wp}}$ and $m_{\mathrm{wad}}$ are the mass flow rate $\left(\mathrm{kg} \mathrm{day}^{-1}\right)$ of substrates water content, added water, and produced water, respectively.

\section{Energy balance}

Having completed mass balances for each stage, the corresponding energy balances are required to determine stage temperatures. In order to construct the energy balance, input and output energies as well as released energy due to the decomposition reactions must be calculated. Total input energy, $H_{\text {toti }}\left(\mathrm{kcal} \mathrm{day}^{-1}\right)$, was determined according to the following equation:

$H_{\text {toti }}=\sum_{i=1}^{N} m_{i} C p_{i}\left[T_{i}-T_{\text {ref }}\right]$

where $N$ is the number of input components, $m_{i}$ is the mass flow rate of component $i\left(\mathrm{~kg} \mathrm{day}^{-1}\right), C p_{i}$ is the specific heat of component $i$ (kcal kg $\left.{ }^{-1}{ }^{\circ} \mathrm{C}^{-1}\right) ; T_{i}$ is the temperature of component $i\left({ }^{\circ} \mathrm{C}\right)$ and $T_{\text {ref }}$ is the reference temperature $\left(=0{ }^{\circ} \mathrm{C}\right)$. This equation is probably the easiest way to compute the energy change caused by temperature change without involving chemical reaction. Total output energy, $H_{\text {toto }}\left(\mathrm{kcal} \mathrm{day}^{-1}\right)$, was determined based on the following equation:

$H_{\text {toto }}=\sum_{j=1}^{M} m_{j} C p_{j}\left[T-T_{\text {ref }}\right]+\left[m_{\mathrm{wvo}}-m_{\mathrm{wvi}}\right] H_{\mathrm{lv}}$

where $M$ is the number of output components, $m_{j}$ is the mass flow rate of component $j\left(\mathrm{~kg} \mathrm{day}^{-1}\right), T$ is the process temperature $\left({ }^{\circ} \mathrm{C}\right)$ and $H_{l v}$ is the latent heat of vaporization for pure liquid water $\left(\mathrm{kcal} \mathrm{kg}^{-1}\right)$. The total released energy, $H_{\text {torg }}\left(\mathrm{kcal} \mathrm{day}^{-1}\right)$, due to the decomposition reaction was calculated by:

$H_{\text {torg }}=\sum_{h=1}^{L} m_{\mathrm{DBVS}_{h}} H_{\mathrm{BVS}_{h}}$

where $L$ is the number of degradable components which entered the process, $m_{\mathrm{DBVS}_{h}}$ is the mass flow rate of degradable component $h\left(\mathrm{~kg} \mathrm{day}^{-1}\right)$, and $H_{\mathrm{BVS}_{h}}$ is the higher heat value of component $h\left(\mathrm{kcal} \mathrm{kg}^{-1}\right)$. Finally, the overall energy balance over each stage was written as follows:

$H_{\text {toti }}+H_{\text {torg }}=H_{\text {toto }}$.

\section{Numerical solution}

In this paragraph, the method for solving the obtained mass and energy balance equations has been discussed. In the model of Haug (1993), total process was broken into a number of well-mixed series stages. The stage temperatures were determined iteratively using heat and mass balance calculations. In other words, mass balance was completed iteratively for the first stage. Having completed the mass balance, the corresponding energy balance was determined for the first stage. If energy balance was not closed, a new temperature should be chosen for the next iteration of the energy balance. This procedure should be repeated until mass and energy balances will be closed for all remaining stages.

\section{Results and discussion}

Model evaluation

In this study, the pilot scale data of Van Gestel et al. (2003) for bioremediation of diesel oil-contaminated soil was used for model validation in which a sample of diesel oilcontaminated soil was remediated by aerobic composting. The soil was spiked with commercial diesel oil at a concentration of $60 \mathrm{~g} \mathrm{~kg}^{-1}$ fresh weight. The polluted soil 
Table 1 Experimental data of diesel oil-contaminated soil bioremediation reported by Van Gestel et al. (2003)

\begin{tabular}{lllll}
\hline $\begin{array}{l}\text { Process } \\
\text { time } \\
(\text { day })\end{array}$ & $\begin{array}{l}\text { Diesel } \\
\text { concentration } \\
C\left(\mathrm{mg} \mathrm{kg}^{-1} \text { dry }\right. \\
\text { mater) }\end{array}$ & $\begin{array}{l}\text { Solid } \\
\text { fraction } \\
\mathrm{SM}\end{array}$ & $\begin{array}{l}\text { Oxygen } \\
\text { concentration } \\
\text { VOLPO }_{2}(\%)\end{array}$ & $\begin{array}{l}\text { Process } \\
\text { temperature } \\
\left({ }^{\circ} \mathrm{C}\right)\end{array}$ \\
\hline 1 & 15,400 & 0.33 & 21.0 & 36 \\
3 & 11,965 & 0.415 & 19.8 & 47.2 \\
6 & 10,760 & 0.415 & 15.5 & 48.5 \\
9 & 9,700 & 0.415 & 8.7 & 69.6 \\
13 & 6,500 & 0.468 & 12.0 & 67.79 \\
21 & 6,120 & 0.455 & 19.0 & 43.6 \\
27 & 5,943 & 0.434 & 20.86 & 29.35 \\
34 & 4,950 & 0.456 & 21.7 & 28.32 \\
41 & 3,120 & 0.456 & 21.7 & 28.0 \\
48 & 3,329 & 0.518 & 21.7 & 25.2 \\
55 & 2,497 & 0.530 & 21.7 & 21.3 \\
62 & 2,705 & 0.530 & 21.7 & 20.6 \\
69 & 3,329 & 0.545 & 21.7 & 18.01 \\
76 & 2,080 & 0.537 & 21.7 & 16.4 \\
85 & 2,395 & 0.530 & 21.7 & 17.4 \\
\hline
\end{tabular}

was mixed with biowaste at a 1:10 ratio (wet weight) and composted in a monitored composting bin system for 12 weeks (Van Gestel et al. 2003). Due to clogging of composting substrates after day 20 , the aeration to diesel oil was hindered; therefore, wood chips $(30 \% \mathrm{w} / \mathrm{v})$ were added as bulking agent to composting mixture on day 29 . During composting operation, several state variables including: temperature, oxygen concentration of the outlet gases and solid content of the composting materials (Van
Gestel et al. 2003) were measured. These data were gathered at days 1, 3, 6, 9, 13, 21, 27, 34, 41, 48, 55, 62, 69, 76 and 85. The measured data of Van Gestel et al. (2003) are depicted in Table 1.

As observed from reported data of Table 1, $84 \%$ reduction in diesel content was reached during the composting of polluted soil. Furthermore, it was demonstrated that a first-order kinetic model fitted well for diesel remediation through aerobic composting.

To examine the model validity, the reported results of Van Gestel et al. (2003) was utilized. Therefore, simulations were accomplished at the same operating conditions of Van Gestel et al. (2003), and the obtained results for diesel degradation and oxygen concentration were compared.

For this purpose, the physical, chemical and thermodynamic properties of all substrates in the process must be previously defined for the model. Furthermore, the necessary kinetics parameters must be established based on the reported data of Van Gestel et al. (2003). As mentioned previously, three substrates including polluted soil, biowaste and woodchips entered the process. It must be mentioned that, Van Gestel et al. (2003) considered a mixture of vegetable/fruit waste, garden waste, and paper as biowaste. As the composition of Van Gestel et al. (2003) biowaste was not reported, it was assumed that the biowaste composed of $40 \%$ vegetable/fruit waste, $40 \%$ garden waste and $20 \%$ paper. The various characteristics of biowaste components and wood chips were collected from Haug (1993) and other references (Cahyari and Putra 2010; Haug 1980; Jolanun et al. 2005). Physical, chemical and thermodynamic properties of biowaste components and substrates are reported in Tables 2 and 3, respectively.

Table 2 Physical, chemical and thermodynamic properties of biowaste components (Cahyari and Putra 2010; Haug 1993, 1980; Jolanun et al. 2005)

\begin{tabular}{|c|c|c|c|c|}
\hline Parameter & Symbol & Fruit/vegetable & Garden waste & Paper \\
\hline Weight $(\mathrm{kg})$ & $X$ & 36 & 36 & 18 \\
\hline Solid fraction & $S$ & $0.15-0.20^{\mathrm{a}, \mathrm{b}}$ & $0.5^{\mathrm{b}}$ & $0.92^{\mathrm{b}}$ \\
\hline Volatile solid fraction & $V$ & $0.83-0.93^{\mathrm{a}, \mathrm{b}}$ & $0.9^{\mathrm{b}}$ & $0.92^{\mathrm{b}}$ \\
\hline Biodegradable volatile solid fraction & BVS & $0.80-0.90^{\mathrm{b}}$ & $0.6^{\mathrm{b}}$ & $0.667^{\mathrm{b}}$ \\
\hline Biodegradable volatile solid fast fraction & BVS FAST & $1.0^{\mathrm{c}}$ & $0.6^{\mathrm{b}}$ & $0.0^{\mathrm{c}}$ \\
\hline Biodegradable volatile solid slow fraction & BVS SLOW & $0.0^{\mathrm{c}}$ & $0.4^{\mathrm{b}}$ & $1.0^{\mathrm{c}}$ \\
\hline Maximum rate constant for fast fraction & RATEKM20F & $0.0126^{\mathrm{c}}$ & $0.01^{\mathrm{b}}$ & $0.0^{\mathrm{c}}$ \\
\hline Maximum rate constant for slow fraction & RATEKM20S & $0.0^{\mathrm{c}}$ & $0.005^{\mathrm{b}}$ & $0.00252^{\mathrm{b}}$ \\
\hline Higher heat of combustion $\left(\mathrm{kcal} \mathrm{kg}^{-1}\right)$ & $H$ & $4,286^{\mathrm{c}}$ & $4,158^{\mathrm{b}}$ & $4,003^{\mathrm{c}}$ \\
\hline Molar carbon & A & $13^{\mathrm{a}}$ & $23^{\mathrm{b}}$ & $266^{\mathrm{c}}$ \\
\hline Molar hydrogen & $\mathrm{B}$ & $22^{\mathrm{a}}$ & $38^{\mathrm{b}}$ & $434^{\mathrm{c}}$ \\
\hline Molar oxygen & $\mathrm{C}$ & $10^{\mathrm{a}}$ & $17^{\mathrm{b}}$ & $210^{\mathrm{c}}$ \\
\hline Molar nitrogen & $\mathrm{D}$ & $1^{\mathrm{a}}$ & $1.0^{\mathrm{b}}$ & $1^{\mathrm{c}}$ \\
\hline Bulk weight coefficient & COEFF & $0.15-0.25^{\mathrm{b}, \mathrm{d}}$ & $0.3^{\mathrm{b}}$ & $0.15-20^{\mathrm{c}}$ \\
\hline
\end{tabular}

${ }^{\mathrm{a}}$ Cahyari and Putra (2010), ${ }^{\mathrm{b}}$ Haug (1993), ${ }^{\mathrm{c}}$ Haug (1980), ${ }^{\mathrm{d}}$ Jolanun et al. (2005) 
Table 3 Physical, chemical and thermodynamic properties of substrates (Cahyari and Putra 2010; Haug 1993, 1980; Jolanun et al. 2005)

\begin{tabular}{|c|c|c|c|c|}
\hline Parameter & Symbol & Contaminated soil & Biowaste & Wood chips \\
\hline Weight $(\mathrm{kg})$ & $X$ & 10 & 90 & 10 \\
\hline Solid fraction & $S$ & 0.75 & 0.283 & 0.6 \\
\hline Volatile solid fraction & $V$ & 0.08 & 0.896 & 0.95 \\
\hline Biodegradable volatile solid fraction & BVS & 1.0 & 0.713 & 0.05 \\
\hline Biodegradable volatile solid fast fraction & BVS FAST & 0.235 & 0.64 & 0.6 \\
\hline Biodegradable volatile solid slow fraction & BVS SLOW & 0.765 & 0.36 & 0.4 \\
\hline Maximum rate constant for fast fraction & RATEKM20F & 0.01226 & 0.00904 & 0.01 \\
\hline Maximum rate constant for slow fraction & RATEKM20S & 0.01226 & 0.002504 & 0.01 \\
\hline Higher heat of combustion $\left(\mathrm{kcal} \mathrm{kg}^{-1}\right)$ & $H$ & 10,700 & 4,178 & 4,297 \\
\hline Molar carbon & A & 12 & 68 & 295 \\
\hline Molar hydrogen & B & 26 & 111 & 420 \\
\hline Molar oxygen & $\mathrm{C}$ & 0.0 & 53 & 186 \\
\hline Molar nitrogen & $\mathrm{D}$ & 0.0 & 1 & 1.0 \\
\hline Bulk weight coefficient & COEFF & - & 0.235 & 0.21 \\
\hline
\end{tabular}

Table 4 Overall reaction rate constants of decomposition diesel

\begin{tabular}{lllllllll}
\hline$t$ (day) & 3 & 3 & 3 & 4 & 7 & 7 & 14 & 21 \\
\hline$k\left(\right.$ day $\left.^{-1}\right)$ & 0.0827 & 0.0367 & 0.0302 & 0.113 & 0.0434 & 0.0514 & 0.0174 & 0.00753 \\
\hline
\end{tabular}

To calculate the degradation rate of diesel under composting condition, the necessary kinetics parameters of diesel degradation (Maximum reaction rate constant at temperature $20{ }^{\circ} \mathrm{C}\left(\right.$ day $\left.^{-1}\right)$ ) must be established based on the data in Table 1. As mentioned previously, the firstorder reaction kinetics was considered for degradation reaction. So, the overall reaction rate constant could be determined according to the following relation:

$\ln \left(\frac{C}{C_{0}}\right)=-k t$

where $C_{0}$ is the initial concentration of diesel oil within the soil, $C$ is the concentration of diesel oil during remediation process, $t$ is time (day) and $k$ is the overall reaction rate constant. The values of overall reaction rate constant according to the Van Gestel et al. (2003) data are given in Table 4.

It is well known that the overall reaction rate constant in composting process is affected by several state variables including moisture content, free air space, oxygen concentration and temperature. The effects of these parameters can be accounted over the $k$ using the Eq. (3).

To impose these effects, the actual state variables of remediation process that are given in Table 1 were used to calculate correction parameters for moisture content, free air space, oxygen concentration and temperature. It should be noted that $k_{T}$ is a complex exponential function of $T$ (Eq. 4), which was developed based on fundamental thermodynamics principles (Arrhenius functions) by Haug (1993). So the effect of the first three parameters was accounted, and subsequently the calculated values of $k_{T}$ at each isotherm of real composting process conditions were fitted to the Eq. (4) for determining $k_{T 2 O}$. The value of maximum reaction rate

Table 5 Operation conditions of Van Gestel et al. (2003) for remediation of diesel oil-contaminated soil

\begin{tabular}{lllll}
\hline Stage & $\begin{array}{l}\text { Stage } \\
\text { duration } \\
t \text { (day) }\end{array}$ & $\begin{array}{l}\text { Solid } \\
\text { fraction } \\
S M\end{array}$ & $\begin{array}{l}\text { Process } \\
\text { temperature } \\
\left({ }^{\circ} \mathrm{C}\right)\end{array}$ & $\begin{array}{l}\text { Ambient } \\
\text { temperature } \\
\left({ }^{\circ} \mathrm{C}\right)\end{array}$ \\
\hline 1 & 1 & 0.33 & 31 & 20 \\
2 & 2 & 0.37 & 38 & 20 \\
3 & 3 & 0.415 & 48 & 20 \\
4 & 3 & 0.415 & 61 & 20 \\
5 & 4 & 0.443 & 70 & 20 \\
6 & 8 & 0.461 & 68 & 20 \\
7 & 6 & 0.444 & 36.6 & 20 \\
8 & 7 & 0.445 & 28.75 & 20 \\
9 & 7 & 0.456 & 28.32 & 20 \\
10 & 7 & 0.487 & 26.76 & 20 \\
11 & 7 & 0.524 & 23.2 & 20 \\
12 & 7 & 0.530 & 21.1 & 20 \\
13 & 7 & 0.537 & 19.3 & 20 \\
14 & 7 & 0.541 & 17.2 & 20 \\
15 & 9 & 0.535 & 16.9 & 20 \\
\hline
\end{tabular}


constant of diesel oil decomposition at $20{ }^{\circ} \mathrm{C}$ under the composting condition was calculated as $0.01226\left(\right.$ day $\left.^{-1}\right)$.

Now, sufficient data for simulation of remediation process are accessible. To validate the model, simulations were run using the operating conditions of Van Gestel et al. (2003) (Table 5), and calculated results for oxygen and diesel concentration were compared with those measured by Van Gestel et al. (2003). The comparisons of oxygen and diesel concentration between the simulations and experimental results are shown in Figs. 1 and 2, respectively.

As observed, there is a reasonable agreement between the simulations and experimental results during the whole period of the remediation process. However, there were many parameters that influenced the composting process, just four of them were considered as the main parameters and the others were ignored. These simplifications as well as the assumptions of homogeneous mixture and uniform diesel concentration are the probable reasons for partial discrepancy between model result and experimental data.

The time behavior of oxygen concentration in the outlet gases is shown in Fig. 2. Due to the high decomposition rate of diesel at the first stages of composting, large amounts of oxygen was consumed. Therefore, carbon dioxide and water vapor concentration in the exit gases increase, but the oxygen concentration decreases. As reaction proceeds, decomposition rate will be decreased which consequently increases the oxygen concentration. At higher reaction time, the decomposition rate is close to zero and the oxygen concentration remains constant. Figure 2 clearly shows that the mathematical model is in agreement with the above physical insight and it is well correlated with the experimental data.

\section{Process optimization}

In this section, the effects of amendment type, bulking agent, amendment/soil ratio and operating conditions including feed moisture content and air flow rate were investigated on diesel biodegradation. Furthermore, the optimum condition for achieving maximum remediation of diesel was determined.
Fig. 1 Comparison between experimental data (Van Gestel et al. 2003) and model predictions for diesel concentration in the remediation process

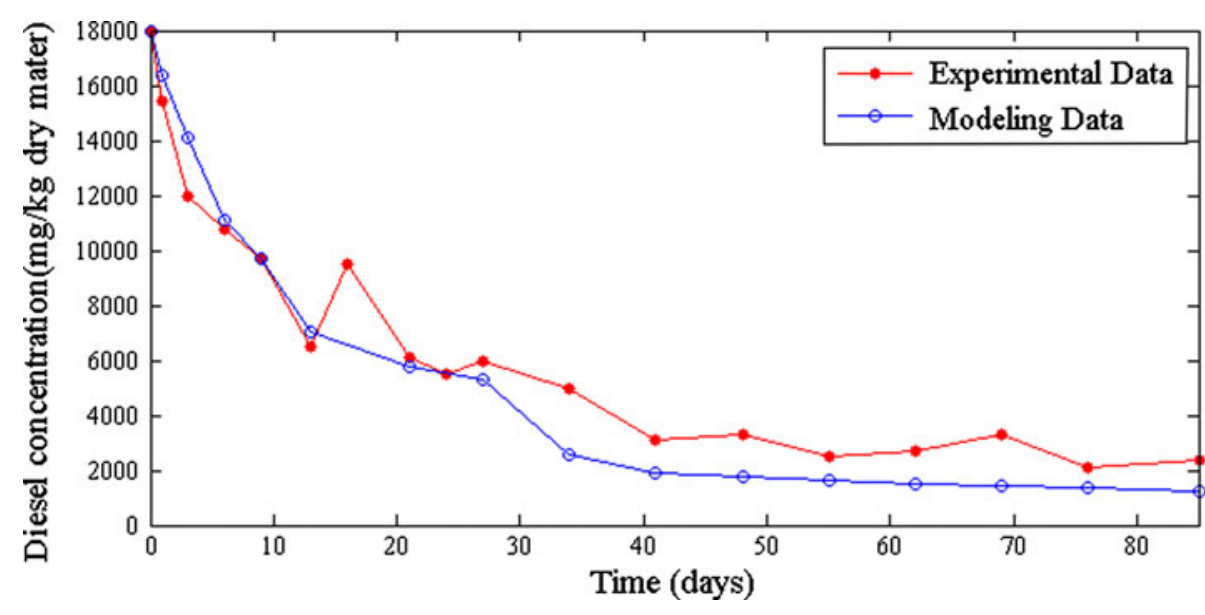

Fig. 2 Comparison between experimental data (Van Gestel et al. 2003) and model predictions for oxygen concentration in composting process

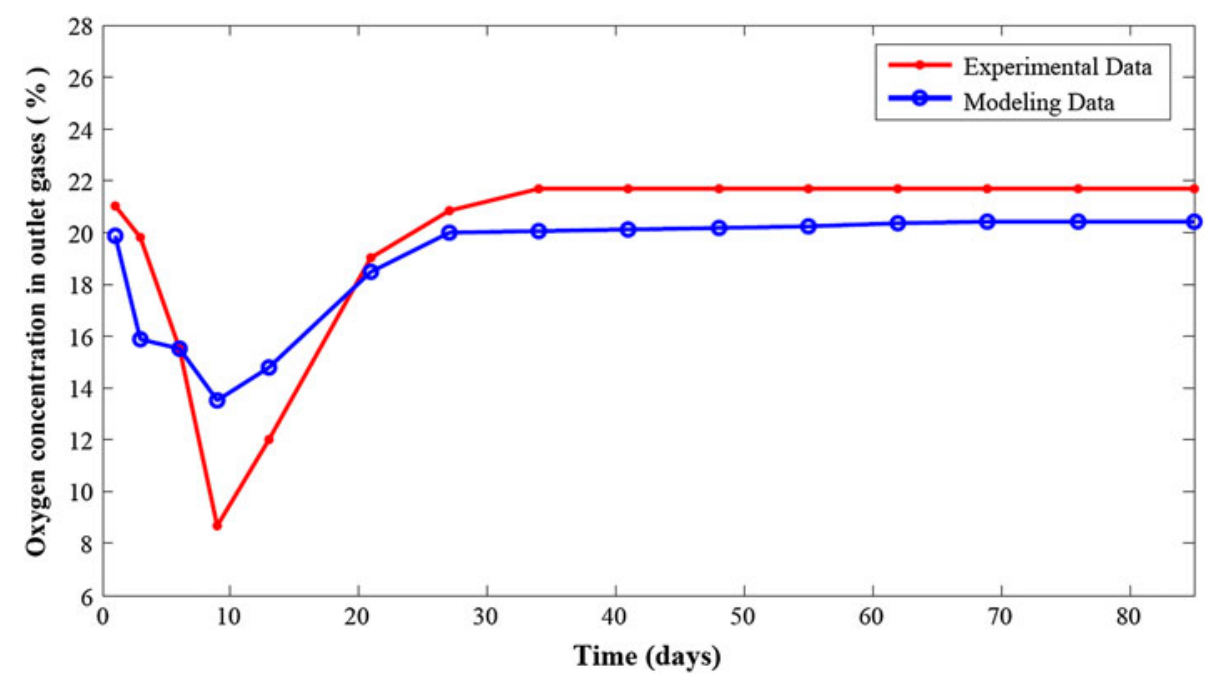


Table 6 Physical, chemical and thermodynamic properties of contaminated soil, amendments and bulking agent substrates (Cahyari and Putra 2010; Haug 1993, 1980; Jolanun et al. 2005)

\begin{tabular}{|c|c|c|c|c|c|c|}
\hline Parameter & Contaminated soil & Yard waste & Sludge & Biowaste & Food waste & Wood chips \\
\hline Weight $(\mathrm{kg})$ & 10 & 30 & 30 & 30 & 30 & 0 \\
\hline Solid fraction & 0.75 & 0.5 & 0.3 & 0.283 & 0.35 & 0.6 \\
\hline Volatile solid fraction & 0.08 & 0.9 & 0.8 & 0.896 & 0.95 & 0.95 \\
\hline Biodegradable volatile solid fraction & 1.0 & 0.6 & 0.65 & 0.713 & 0.6 & 0.05 \\
\hline Biodegradable volatile solid fast fraction & 0.235 & 0.6 & 0.4 & 0.64 & 0.7 & 0.6 \\
\hline Biodegradable volatile solid slow fraction & 0.765 & 0.4 & 0.6 & 0.36 & 0.3 & 0.4 \\
\hline Maximum rate constant for fast fraction & 0.01226 & 0.01 & 0.015 & 0.00904 & 0.05 & 0.01 \\
\hline Maximum rate constant for slow fraction & 0.01226 & 0.005 & 0.005 & 0.002504 & 0.005 & 0.01 \\
\hline Higher heat of combustion ( $\mathrm{kcal} \mathrm{kg}^{-1}$ ) & 1,0700 & 4,158 & 5,267 & 4,178 & 5,267 & 4,297 \\
\hline Molar carbon & 12 & 23 & 10 & 68 & 16 & 295 \\
\hline Molar hydrogen & 26 & 38 & 19 & 111 & 27 & 420 \\
\hline Molar oxygen & 0.0 & 17 & 3 & 53 & 8 & 186 \\
\hline Molar nitrogen & 0.0 & 1.0 & 1 & 1 & 1 & 1.0 \\
\hline Bulk weight coefficient & - & 0.3 & 0.21 & 0.235 & 0.26 & 0.21 \\
\hline
\end{tabular}

Table 7 Applied operational conditions to investigate the effect of amendment type on diesel remediation

\begin{tabular}{lllllll}
\hline $\begin{array}{l}\text { Number of } \\
\text { stages }\end{array}$ & $\begin{array}{l}\text { Time of each } \\
\text { stage (day) }\end{array}$ & $\begin{array}{l}\text { Solid } \\
\text { fraction SM }\end{array}$ & $\begin{array}{l}\text { Air flow rate } \\
\left(\mathrm{m}^{3} \mathrm{day}^{-1} \mathrm{kgBVS}^{-1}\right)\end{array}$ & $\begin{array}{l}\text { Ambient } \\
\text { temperature }\left({ }^{\circ} \mathrm{C}\right)\end{array}$ & $\begin{array}{l}\text { Relative } \\
\text { humidity }(\mathrm{RH})\end{array}$ & $\begin{array}{l}\text { Amendments/soil } \\
\text { ratio }\left(\mathrm{kg} \mathrm{kg}{ }^{-1}\right)\end{array}$ \\
\hline 10 & 3 & 0.4 & 0.50 & 20 & 0.5 & 3 \\
\hline
\end{tabular}

\section{Effect of amendments}

To determine the effect of amendment type on diesel biodegradation, several amendments including yard waste, sludge, biowaste and food waste were used for remediation process. Physical, chemical and thermodynamic properties of contaminated soil, amendments and bulking agent are given in Table 6. The characteristics of yard waste, sludge, and food waste were adapted from Haug (1993), and the given values in Table 3 were considered for biowaste characteristics.

As shown in Fig. 1, the majority of diesel was degraded during the first 30 days of remediation process, so simulations were accomplished only for the first 30 days of remediation process. For this purpose, $10 \mathrm{~kg}$ of dieselcontaminated soil with concentration of 60 (g diesel $/ \mathrm{kg}$ fresh soil) was considered for remediation. Simulation was accomplished for each amendment according to the operating condition in Table 7.

The percentage of the decomposed diesel versus process time for each amendment is shown in Fig. 3. As observed, at the first 10 days of the remediation process the decomposition curve has a steep slope for all amendments, afterwards the slope of the curves increase gradually and after the day 20 increasing the process time do not influence the diesel biodegradation considerably. Furthermore, it is observed that the maximum degradation of diesel occurred in the presence of yard waste amendment, and the food waste has the minimal effect on diesel degradation in comparison with other amendments. To make this result more clear, it should be noted that various factors such as process temperature, moisture content, oxygen concentration and free air space (FAS) have influenced the biodegradation reaction. On the other side, according to the Eq. (3) an amendment with lower density has a desirable effect on diesel biodegradation, and an amendment with high reaction rate constant and high heat value may restrict the diesel biodegradation. In summary, complex interactions of these parameters and their effects determine the biodegradation behavior of diesel in remediation model.

\section{Effect of bulking agent}

According to the Eqs. $(6,8,10)$, increasing the free air space and decreasing the density of the composting matrix may enhance the diesel biodegradation. So, the effect of a bulking agent was investigated on diesel biodegradation. For this purpose, wood chips were added to the composting matrix as a bulking agent in the presence of the abovementioned amendments. The characteristics of wood chips were adopted from Haug (1993) and given in Table 6. It must be noted that for each simulation $15 \mathrm{~kg}$ amendment 
Fig. 3 Profile of diesel decomposition with time for different amendments

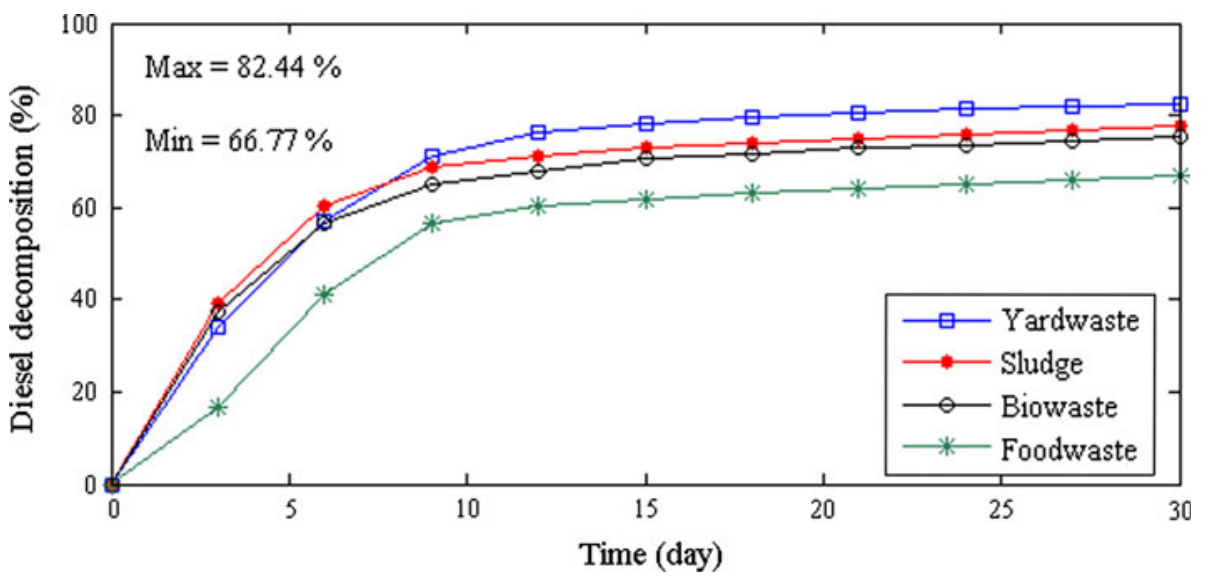

and $15 \mathrm{~kg}$ bulking agent were used and the ratio of (amendment and bulking agent)/soil was 3 .

The predicted results are shown in Fig. 4. As can be seen, addition of wood chips enhances the diesel biodegradation. For example, the value of decomposed diesel after day 30 in presence of yard waste amendment is increased from 82.44 to $88.66 \%$. So, addition of bulking agent has increased the diesel degradation about $6 \%$. As mentioned previously, addition of wood chips increases the free air space of composting matrix, which is responsible for promotion of diesel degradation.

\section{Effect of amendment/soil ratio}

In the previous sections, it was illustrated that the yard waste is an effective amendment for remediation of dieselcontaminated soils. So, in the following sections, the effects of remaining parameters were investigated only for yard waste. The remaining parameters, which may affect the diesel degradation, are the amendment/soil and bulking agent/soil ratios. To examine the effects of these two parameters on diesel degradation, both of them were varied from 0 to 5 at the constant operating conditions of Table 7. The simulation results are represented in Fig. 5.
As can be seen, addition of the amendment and bulking agent has a great influence on diesel biodegradation, especially when the ratios are changed from 0 to 2 . With increase of amendment/soil and bulking agent/soil ratios, the physical parameters and chemical composition of composting matrix were altered and the decomposition reaction was mainly influenced. As observed the maximum value of diesel degradation was occurred at amendment/ soil $=2.5$ and bulking agent/soil $=2.25$. For higher values of these two parameters, the rate of diesel degradation approximately remained constant.

\section{Effect of operating condition}

To guarantee the growth and activity of microorganism's population in composting process, appropriate conditions must be provided for them. In other words, microbial population is affected by environmental conditions such as temperature, moisture and oxygen concentration. So, desirable values of these variables should be established for optimum removal of diesel in polluted soil. The most important operating parameters, which directly influence the environmental conditions within the composting matrix, are air flow rate and moisture content.
Fig. 4 Profile of diesel decomposition with time in presence of bulking agent and different amendments

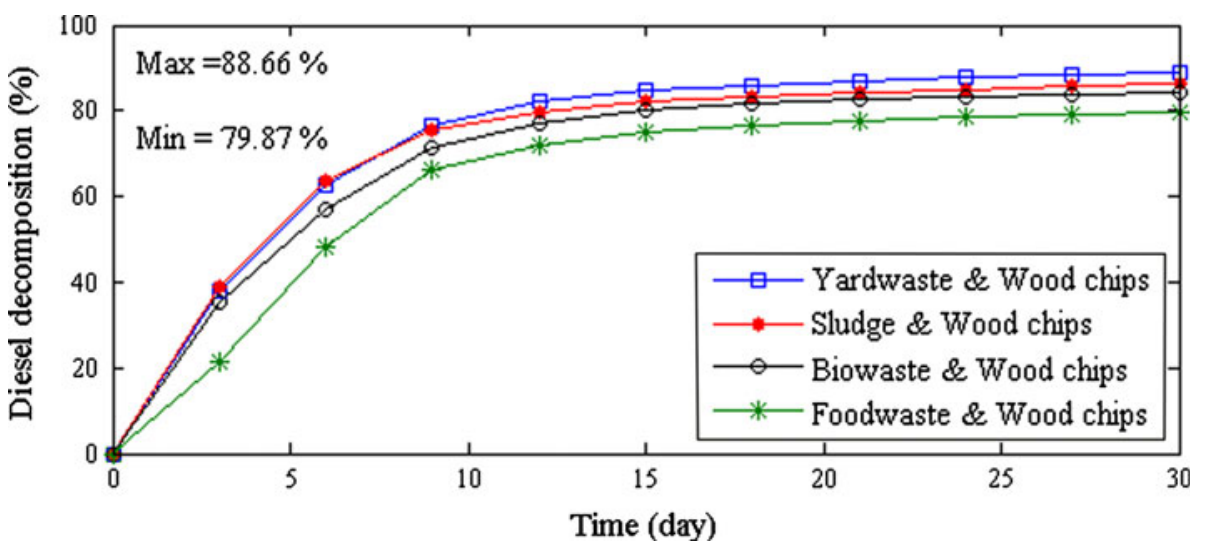


Fig. 5 Profile of diesel decomposition for different ratio of amendment/soil and bulking agent/soil

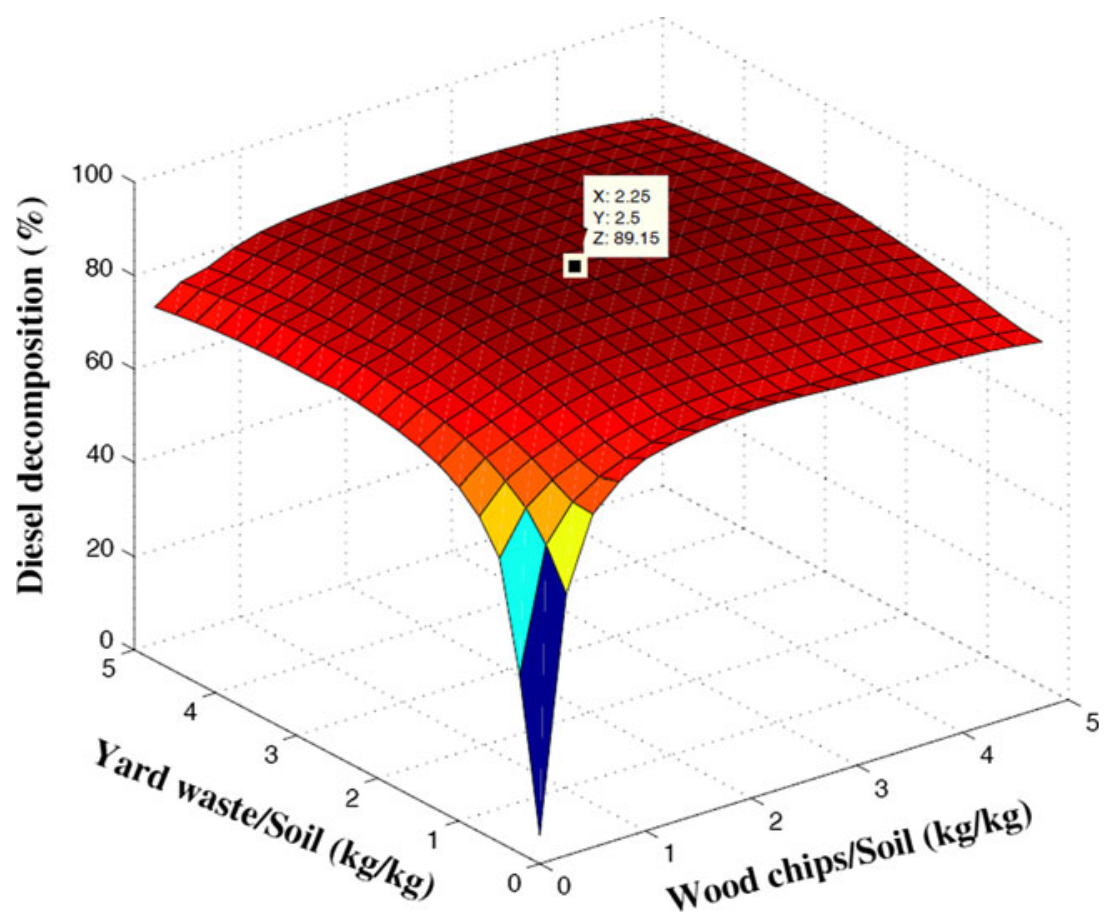

Fig. 6 Effect of moisture content and air flow rate on diesel decomposition with yard waste and wood chips

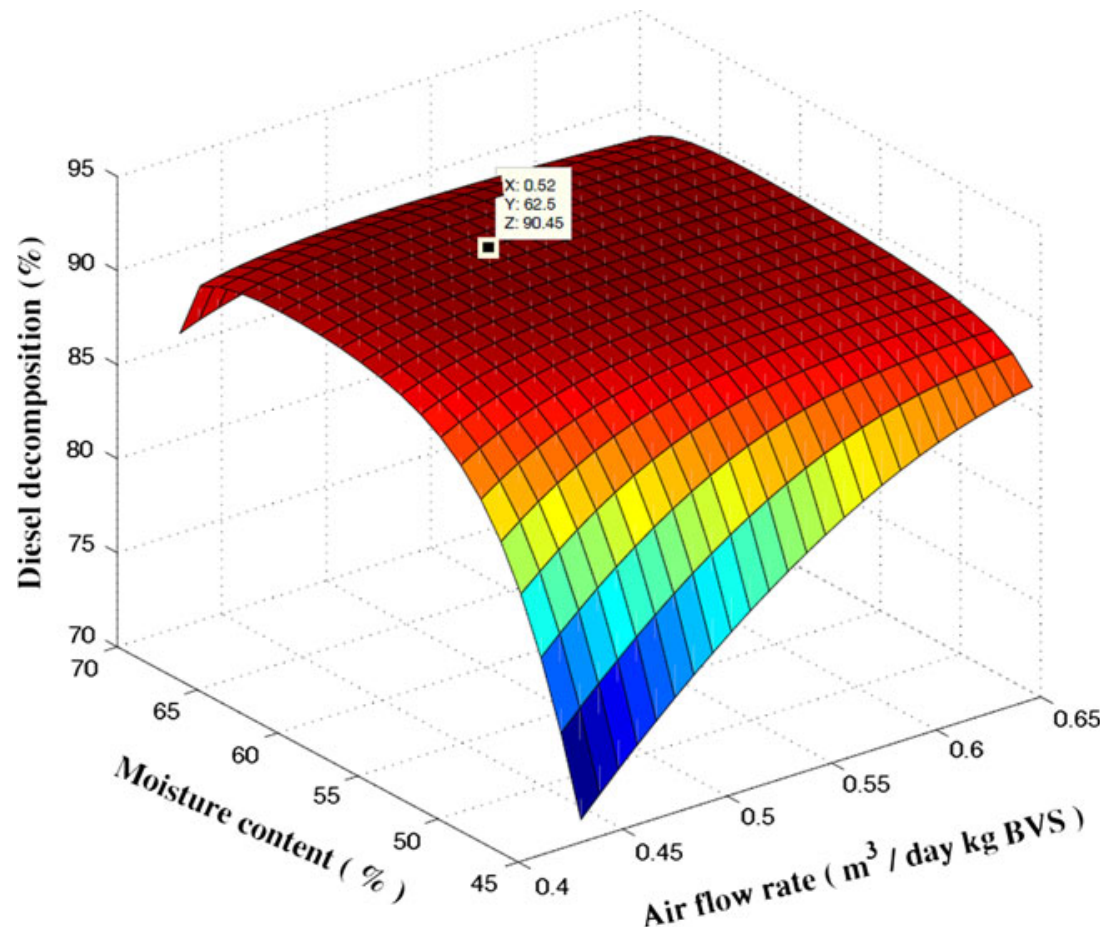

To investigate the effect of these operating parameters on diesel degradation, simulation tests were accomplished for selected amendment, yard waste, at the optimum ratios of amendment/soil and bulking agent/soil. For this purpose, air flow rate was changed from 0.430 to $0.650 \mathrm{~m}^{3}$ day $^{-1} \mathrm{kgBVS}^{-1}$ and moisture content was changed from 45 to $70 \%$. The calculated results are shown in Fig. 6. As observed, at high and low values of air flow rate and moisture content, the decomposed diesel surface experiences a descending trend when approaching the boundaries. This happened because at low moisture content, the $F 1$ correction factor decreases and with increase of moisture content $F 1$ experiences an opposite behavior. At higher values of moisture content although $F 1$ increases, 
F2 declines. Therefore, optimum moisture content should be within the operating condition ranges. As can be seen, $90.45 \%$ of diesel oil has decomposed as a maximum value at $0.520 \mathrm{~m}^{3} \mathrm{day}^{-1} \mathrm{kgBVS}^{-1}$ of air flow rate and $62.5 \%$ of moisture content.

\section{Conclusion}

In this work by merging the mass and energy balance relations with reaction kinetics, a mathematical model has been developed to predict the remediation of petroleum hydrocarbon-contaminated soil by aerobic composting process. The model was solved using an iterative method. To validate the model, simulation results were compared with the experimental data of Van Gestel et al. (2003), which were obtained for bioremediation of diesel oil-contaminated soil by aerobic composting. The comparison showed that the model results in general are in a good agreement with the experimental data especially at initial time of the process. It should be noted that many parameters including moisture content, free air space, oxygen concentration, temperature, lack of degradable organics, imbalanced $\mathrm{pH}$ conditions, lack of inorganic nutrients, lack of microbes, and the toxic substance can limit the reaction kinetics. However, a comprehensive description of composting kinetics based on first principles is not practical. In this study, just the effects of the first four parameters were considered on composting kinetics and the effects of the other parameters were ignored. These simplifications as well as the assumptions of homogeneous mixture and uniform diesel concentration are the probable reasons for partial discrepancy between model result and experimental data. In the other part of the current study, a sensitivity analysis has been applied to study the effect of amendment type, bulking agent, amendment/soil ratio, bulking agent/ soil ratio and operating conditions on the diesel biodegradation. In the first step, yard waste, sludge, biowaste and food waste were used as amendments to study their influence. Results revealed that the maximum and minimum degradation of diesel has been obtained for yard waste and food waste, respectively. In the next step, the influence of amendment/soil and bulking agent/soil ratios has been studied on the diesel decomposition. The results indicate that changing these ratios from 0 to 2.5 has a great effect on the diesel decomposition and increase it from 0 to about 90 . Further increase in these ratios has a little effect so that diesel decomposition is almost independent of them. The results also show that the maximum diesel decomposition obtained for amendment/soil and bulking agent/soil equals to 2.5 and 2.25 , respectively. In order to complete the sensitivity analysis, the effect of air flow rate and moisture content as the main operation conditions have been investigated on the diesel decomposition. As expected, diesel decomposition is an ascending-descending function of these two parameters, and the optimum operational conditions occurred for $0.520 \mathrm{~m}^{3} \mathrm{day}^{-1} \mathrm{kgBVS}^{-1}$ of air flow rate and $62.5 \%$ of moisture content.

Acknowledgments This research was financially supported by the National Iranian Oil Products Distribution Company (Contract no.: 16/900518).

\section{References}

Abdulsalam S, Bugaje IM, Adefila SS, Ibrahim S (2011) Comparison of biostimulation and bioaugmentation for remediation of soil contaminated with spent motor oil. Int. J. Environ. Sci. Tech. 8(1):187-194

Adams RH, Guzmán-Osorio FJ (2008) Evaluation of land farming and chemico-biological stabilization for treatment of heavily contaminated sediments in a tropical environment. Int. J. Environ. Sci. Tech. 5(2):169-178

Al-Daher R, Al-Awadhi N, El-Nawawy A (1998) Bioremediation of damaged desert environment using the windrow soil pile system in Kuwait. Environ Int 24:175-180

Antizar-Ladislao B, Lopez-Real J, Beck AJ (2004) Bioremediation of polycyclic aromatic hydrocarbon (PAH)-contaminated waste using composting approaches. Crit Rev Environ Sci Technol 34:293-302

Bento FM, Camargo FAO, Okeke BC, Frankenberger WT (2005) Comparative bioremediation of soils contaminated with diesel oil by natural attenuation, biostimulation and bioaugmentation. Bioresour Technol 96:1049-1055

Cahyari K, Putra RA (2010) Design of biogas plant from fruit market waste in Indonesia. Renewable Energy Conference, Berlin

Chaineau CH, Rougeux G, Yepremian C, Oudot J (2005) Effects of nutrient concentration on the biodegradation of crude oil and associated microbial populations in the soil. Soil Biol Biochem 37:1490-1497

Fountoulakis MS, Terzakis S, Georgaki E, Drakopoulou S, Sabathianakis I, Kouzoulakis M, Manios T (2009) Oil refinery sludge and green waste simulated windrow composting. Biodegradation 20:177-189

Freeman HM, Harris EF (1995) Composting of contaminated soil. In: Freeman HM, Harris EF (eds) Hazardous waste remediation: innovative treatment technologies. Technomic Publishing Company Inc, Lancaster, pp 73-85

Gallego JLR, Loredo J, Llamas JF, Vázquez F, Sánchez J (2001) Bioremediation of diesel-contaminated soils: evaluation of potential in situ techniques by study of bacterial degradation. Biodegradation 12:325-335

Haug RT (1980) Compost engineering principles and practice. Ann Arbor Science Publishers Inc., Ann Arbor

Haug RT (1993) The practical handbook of compost engineering. Lewis Publishers, Boca Raton

Hwang E-Y, Park J-S, Kim J-D, Namkoong W (2006) Effects of aeration mode on the composting of diesel-contaminated soil. J Ind Eng Chem 12:694-701

Jolanun B, Tripetchku S, Chiemchaisri C, Chaiprasert P, Towprayoonr S (2005) The application of a fed batch reactor for composting of vegetable and fruit wastes. Thammasat Int. J. Sc. Tech. 10:60-69

Jorgensen KS, Puustinen J, Suortti A-M (2000) Bioremediation of petroleum hydrocarbon contaminated soil by composting in biopiles. Environ Pollut 107:245-254 
Mason IG (2006) Mathematical modelling of the composting process: a review. Waste Manage 26:3-21

Megharaj M, Ramakrishnan B, Venkateswarlu K, Sethunathan N, Naidu R (2011) Bioremediation approaches for organic pollutants: a critical perspective. Environ Int 37:1362-1375

Namkoong W, Hwang E-Y, Park J-S, Choi J-Y (2002) Bioremediation of diesel contaminated soil with composting. Environ Pollut 119:23-31

Obire O, Anyanwu EC (2009) Impact of various concentrations of crude oil on fungal populations of soil. Int. J. Environ. Sci. Tech. 6(2):211-218

Petric I, Selimbasic V (2008) Development and validation of mathematical model for aerobic composting process. Chem Eng 139:304-317

Riser-Roberts E (1992) Bioremediation of petroleum contaminated sites. CRC Press, Boca Raton
Van Gestel K, Mergaert J, Swings J, Coosemans J, Ryckeboer J (2003) Bioremediation of diesel oil contaminated soil by composting with biowaste. Environ Pollut 125:361

Yousefi Kebria D, Khodadadi A, Ganjidoust H, Badkoubi A, Amoozegar MA (2009) Isolation and characterization of a novel native Bacillus strain capable of degrading diesel fuel. Int. J. Environ. Sci. Tech. 6(3):435-442

Zhao YC, Yi XY, Zhang M, Liu L, Ma WJ (2010) Fundamental study of degradation of dichlorodiphenyltrichloroethane in soil by laccase from white rot fungi. Int. J. Environ. Sci. Tech. 7(2): 359-366

Zhu X, Venosa AD, Suidan MT, Lee K (2001) Guidelines for the bioremediation of marine shorelines and freshwater wetlands. US Environmental Protection Agency, Cincinnati. http://www. epa.gov/oilspill/pdfs/bioremed.pdf 